Kansas State University Libraries

New Prairie Press

International Symposium for Innovative

2017 International Symposium on Innovative

Teaching and Learning

Teaching and Learning

\title{
How Collaborative Teaching Benefits Teachers, Students, and Programs
}

April M. Darnell

Kansas State University, adarnell@ksu.edu

Follow this and additional works at: https://newprairiepress.org/isitl

Part of the Other Teacher Education and Professional Development Commons

(c) (1) (3) (-)

This work is licensed under a Creative Commons Attribution-Noncommercial-Share Alike 4.0

License.

\section{Recommended Citation}

Darnell, April M. (2017). "How Collaborative Teaching Benefits Teachers, Students, and Programs," International Symposium for Innovative Teaching and Learning. https://doi.org/10.4148/2573-4911.1017

This Poster is brought to you for free and open access by the Conferences at New Prairie Press. It has been accepted for inclusion in International Symposium for Innovative Teaching and Learning by an authorized administrator of New Prairie Press. For more information, please contact cads@k-state.edu. 
How do we define collaborative teaching? Collaborative teaching: "Any academic experience in which two itself uses group learning techniques" (Robinson \& Schaible, 1995) Co-teaching: The traditional concept in which 2 teachers share or divide responsibility for planning, designing curriculum, teaching, and assessing the same group of students

I developed a structure in an Intensive English Program (IEP) in Collaborative Course Teams (CCT's): A structure in which two or Collaborative Course Teams (CCT's): A structure in which two or that each teaches independently, but simultaneously, in an

academic term. Teachers create a community of practice centered around the course as its domain of interest.

What are Communities of Practice?

A term coined by learning theorist Etienne Wenger and

Communities of practice are groups of people who engage in a process of collective learning in a shared domain of human endeavor." These communities of practice "share a concern or a passion for something they do and learn how to do it better as They interact regularly" (wengen.

Three parallel elements of communities of practice:

1. Members have a shared domain of interest.

2. Members take part in joint activities and discussions, help one another, and share
knowelege.
3. Members are practitioners or professionals sharing resources and expertise over time.

How Collaborative Course Teams Work

The curriculum coordinator(s) selects CCT Leaders, who:

Start with a strong set of student learning outcomes (SLO's), objectives, and sample syllabus developed in conjunction with the curriculum coordinator

Work with the rest of the CC Team to decide which topics/chapters of the textbook(s) to cover to help students meet SLO's

Work out a calendar with dates of proposed quizzes, tests, and due dates for major assignments listed

Organize the effort to write assessments, develop rubrics, etc.

Share ideas, materials, and lesson plans with the team as

desired

Communicate with the appropriate administrator for support

Communicate with the rest of the team-especially new

instructors

To make this structure work, these roles must be clearly

communicated in multiple modes to all stakeholders.

\section{How does collaboration benefit programs? How does collaborative teaching benefit teachers?}

Teacher collaboration can help programs achieve institutional, program, and curricular goals by making teachers better aware of best practices and practices that are best-suited for a particular context.

$$
\begin{aligned}
& \text { - Collaborative learning benefits students by: } \\
& \text { Fostering higher achievement } \\
& \text { Leading to greater retention/persistence } \\
& \text { Improving interpersonal skills } \\
& \text { Increasing regard for positive interdependence } \\
& \text { (Robinson \& Schaible) } \\
& \text { Contributing toward group goals increases } \\
& \text { students' commitment to said goals and to the } \\
& \text { group (Dornyei) }
\end{aligned}
$$

\section{My experience with} collaborative teaching

Intensive Program A

10-week, intensive quarters

- Ader 100 students, 1 or 2 sections per course

Adjunct, part-time load, to Adjunct, full teaching

load

- Co-teaching as a matter of practicality:

overloaded classes, classroom shortages

(In telationship (In terms of program experience)

between two teachers in the same class

accomplishes multiple goals

Less effective with two teachers of similar levels of

experience-personal dynamics

Teachers of all skills in a level collaborated via e-

mail and weekly meetings

\section{Intensive Program B}

nsive, 7-week terms

- Rapid growth, from @ 100 to 250+ in approx.18

Adjunct, pa

full-time staff, full load

Program Transitioned from 1 or 2 sections to multiple sections of courses $=$ more instructors \& adjuncts hired $=$ less standardization of curriculum, differing levels of course quality

- Limited Collaborative structure, but roles not equally weighted among FT \& adjunct. Program pace, schedule $=$ collaboration more challenging than

gratifying for primary instructors

No centralized structure for facilitating collaboration among primary course instructors = inconsistency, frustration

Intensive Program B 2.0

Administrative Structure for Collaborative Course Teams

\section{Program Manager}

Associate Program Manager 1 (APM) for Levels 4 \& 5

Associate Program Manager 2 for Levels 1,2 \& 3
Collaborative Course Team Leaders for each course (faculty or IEP veteran adjunct instructors)

Course Instructors
The Future of Cullaborative Teaching Approaches

With the widespread adoption of blended learning models around the world, new joint teaching models have emerged:

(Yang et al.)

1. On-site leadership: On-site teachers organize course content that includes both direct content delivery and delivery of digital

2. Off-site leadership: The off-site teacher delivers the content
via two-way videoconferencing while the on-site teacher organizes student participation, provides face-to-face student support, and

evaluates students' performance.

3. Digital co-teaching: Two or more geographically distant teachers co-design activities which require student collaboration online.

Collaborative teaching benefits teachers, students, and programs:

Helps maintain student-centered classrooms

Reinforces new styles of teaching and innovative approaches

Fosters more effective classroom practices when success stories are

support and encouragement

Contributes to the

higher education

Is essential in
populations

\section{References}

Blanchard K.D. (2012) Modeling lifelong learning: Collaborative Blanchard, K.D. (2012) Modeling lifelong learning: Collaborative
teaching across disciplinary lines. Teaching Theology and Religion, $15(4), 338-355$.

Dornyei, Z. (2014). Motivation in second language learning. In Teaching english as a second or foreign language(4th ed., pp. 518-531). Heinle.

Esterby-Smith, M., \& Olve, N. (1984) Team teaching: Making management education more student-centered? Management learning, 15(3), 221-236.

Nevin, A.I., Thousand, J.S., \& Villa, R.A. (2009) Collaborative Teaching and teacher education, 25, 569-574. Robinson, R., \& Schaible, R. (1995) Collabo
the benefits. Coll lege Teaching $43(2)$, 57-60.

Rytivaara, A. \& Kershner R. (2012) Co-teaching as a context for teachers' professional learning and joint knowledge construction. Teaching and Teacher Education, 28, 999-1008. Wenger, E. (n.d.) Communities of practice: A brief introduction. content/uploads/2012/01/06-Brief-introduction-to-communities-o

Yang, H. H., Zhu, S., \& Macleod, J. (2016). Collaborative teaching approaches: Extending current blended learning models. Lecture Practices, 49-59. doi:10.1007/978-3-319-41165-1_5 